Conference Paper

\title{
Healthy Snack for Diabet Patients with Cocoyams Tubers
}

\author{
Dedin Finatsiyatull Rosida*, Fetty Tri Anggraeni \\ Universitas Pembangunan Nasional “Veteran” Jawa Timur, Indonesia
}

*Corresponding author:

E-mail: dedin.tp@upnjatim.ac.id

\begin{abstract}
Diabetes Mellitus sufferers are estimated to have reached 9.1 million people. This data makes Indonesia ranked 5 th in the world with the highest Diabetes Mellitus. Diabetes Mellitus is one of the main causes of non-communicable diseases or $2.1 \%$ of all deaths, including East Java province. The key to managing blood sugar levels is managing carbohydrate intake. This is because carbohydrates are responsible for raising blood sugar levels. Managing the number of carbohydrates is the main goal, although choosing slow-digesting carbohydrates with high fiber content. Apart from carbohydrates, diabetics also need to limit their intake of salt, saturated fats and avoid trans fats. People with diabetes need to include fiber and healthy fats in their daily diet. People with diabetes have a higher risk of developing hypertension, high cholesterol, and heart disease than the general population. It is very important to consider these risks when planning a diet. For that, we need snacks that are low in calories and have high levels of dietary fiber and low trans fat content. UPN Veteran Jawa Timur through the Community Innovation Service Program (BIMA) provides training to UD. Rinjani Cookies to produce various snacks made from cocoyam tubers (Kimpul) with high enough healthy nutrition. The snack products offered were cookies, brownies, kimpul layers cake, and kimpul banana cakes. This snack is healthy for people with Diabetes Mellitus because it is rich in fiber, low calory, and does not contain trans fats.
\end{abstract}

Keywords: Diabetics, healthy snacks, kimpul, low calories.

\section{Introduction}

It has become a phenomenon in today's consumer life, preferring fast food or snacks and high calories foods. This situation will be very dangerous to threaten people's health in the future. Especially with foods that contain high sugar, artificial coloring agents, ingredients with low quality and unbalanced nutritional content, with poor and unhealthy lifestyles. Now, Indonesia is said to be among the largest countries with diabetes in the world.

Foods with a low glycemic index will reduce the rate of glucose absorption and suppress the secretion of the pancreatic hormone insulin so that blood sugar levels do not spike. The glycemic index of a food is influenced by several factors including fiber content, amylose and amylopectin ratio, fat and protein content, and starch digestibility (Istiqomah \& Ristanti, 2015).

One of the factors causing the high prevalence of diabetes mellitus is the consumption pattern. Lifestyle changes also affect people's consumption patterns, resulting in a lack of attention to the food consumed. Foods with a high glycemic index (GI) will increase blood glucose levels in the long term, causing various complications of diabetes problems. Consumption of foods that contain a high glycemic index can cause insulin resistance. According to Mayawati and Farida (2017) state diabetes mellitus patients experience a decrease in glucose levels after consuming foods with a low glycemic index.

Based on that phenomenon, we must be aware of the importance of keeping a balanced and healthy diet. Rinjani Cookies as a home industry that produce cakes and snacks has been given the

\section{How to cite:}

Krishanti, N. P. R. A., Zulfiana, D., \& Wikantyoso, B. (2021). Antimicrobial production by an actinomycetes isolated from the termite nest. $5^{\text {th }}$ International Seminar of Research Month 2020y. NST Proceedings. pages 286-290. doi: $10.11594 /$ nstp.2020.0944 
training to produce the healthy cake and snack products for the community. Management of production and processing of raw materials is correct based on the quality of cakes for sufferers and prevention of diabetes according to standards. This cake/snack business opportunity to prevent diabetes can be carried out at the household scale and small and medium business groups (UKM). The raw materials are non-gluten flour, namely kimpul tuber flour, and the addition of non-trans fat, non-sucrose sugar, and the addition of beta-stimulating spices for pancreatic cells and shallots to increase health functions. Kimpul flour is rich in dietary fiber and is easy to digest in the body. Rinjani Cookies home industry business has been running for a long time, but in its journey, this business product still experiences several weakness including There is not yet a variety of cake/snack products that exist, especially for consumers with and those that prevent diabetes.

\section{Material and Methods \\ Implementation method}

The approach method offered to the problems faced by the Rinjani Cookies micro-business group is the application of kimpul tuber flour, non-trans fat and non-sucrose sugar as raw materials for cakes and various processed products. Also, assistance was provided for online marketing, and attended boot camp training from the inbis of UPN Veteran Jawa Timur to improve sales skills.

The activities to be carried out can be described as follows:

1. Providing counseling and training as well as assistance to Rinjani Cookies regarding the correct system for providing cakes/snacks for diabetes

2. Providing counseling and training as well as assistance to Rinjani Cookies in making attractive and environmentally friendly packaging for cake/snack products for diabetes.

3. Provides skills in selling Rinjani Cookies products online. Training on how to provide diversification of cakes and snacks Rinjani Cookies is carried out in several steps. The steps taken before training were;

a. Identifying various local raw materials that are considered potential as antidiabetic and antioxidants (repairing pancreatic beta cells) to be used as a composition for healthy cakes/snacks produced by Rinjani Cookiess.

b. Applying making cakes/snacks for the health of diabetics in each composition of the formulas that were compiled. The goal is to obtain cakes/snacks with the best quality and contain high dietary fiber, low calories, low fat, and rich in antioxidants as diabetes prevention, then use as a diversified product of Rinjani Cookies.

c. Measure levels of protein, carbohydrates, and fat, for the cakes that were made.

4. Providing counseling and training to Rinjani Cookies about diversifying the processing of its cake/snack produced so as not to bore consumers.

5. Help increase the production of Rinjani Cookies through the addition of processing facilities and infrastructure.

6. Provide assistance and training to Rinjani Cookies in online marketing to promote Rinjani Cookies diversified products' brands.

7. Outreach and demonstrations were carried out at meeting intervals with a face-to-face training system, counseling, and discussions. The materials presented were (1) Food for health for diabetics, (2) Training on the correct preparation of healthy food (3) Training on how to diversify cake/snack products. 4) Marketing assistance

\section{Result and Discussion}

Cookies that are often served during Eid contain very high calories, especially sugar content. In order not to cause blood sugar to rise, cookies are made less sweet. To avoid cholesterol to rise, avoid cookies that contain too much butter. Because they do not use preservatives, healthy cookies 
must pay attention to cleanliness and a grace period for storage. Healthy cookies should be consumed for no more than one month. Eating cookies is healthy. Keep in mind, not a lot of portions. Several pieces at a time. We recommend you to eat this cake when you are full because when we are hungry, we cannot control ourselves to eat less.

High-carbohydrate food ingredients include sugar, rice, wheat, tubers, corn, bread, noodles, rice noodles, porridge, potatoes, biscuits, as well as sago. Foods with carbohydrate content almost pure or close to 100 percent are granulated sugar. All types of vegetables contain carbohydrates, but because of their high fiber content, they are included in low-carbohydrate foods.

Fiber is a carbohydrate class as well, but because the human intestine cannot digest plant fiber, the fiber cannot be digested into monosaccharides. Carbohydrates can be friends or enemies depending on how we eat them.

Diabetes Mellitus (DM) is a non-contagious degenerative disease that is a serious problem for public health in Indonesia and in the world (Krisnatuti \& Yehrina, 2008). Irregular eating patterns that occur in society today can cause an increase in the number of degenerative diseases, one of which is DM (Suiraoka, 2012). DM sufferers must pay attention to the diet which includes the schedule, amount, and type of food consumed. Blood sugar levels increase drastically after consuming certain foods because the tendency of the food consumed has uncontrolled blood sugar content (Tandra, 2009)

Composition of nutrients per day recommended for diabetics:

Carbohydrate : $60-65 \%$ of total calories

Fat $\quad: 20-25 \%$ of total calories

Protein $\quad: 15-20 \%$ of total calories

Sugar $\quad: \leqslant 5 \%$ of total calories

Cholesterol $:: 300 \mathrm{mg}$

Fiber $\quad: 30 \mathrm{mg}$

Salt $\quad:<69$ gr $( \pm 1$ tsp $)$

Pastries are preferred when celebrating holidays, such as Eid. Almost in every house, there are always castles, nastar, snow-white, and others. Towards Eid, many home industries, UKM, and large industries produce cookies. Various cookies are offered. Similarly with them, UD. Rinjani Cookies offers a variety of cookies and brownies. Cookies are delicious, but it should be considered that each piece of cookies contains no less than 50 calories. If you eat 10 pieces, you unconsciously spend 500 calories or a quarter of your daily calorie needs. The average calories requirement for an adult a day is around 2,000 calories. Recently, the awareness to live healthy has also encouraged the efforts of people to make cookies so that they are still delicious to eat without causing illness in the future.
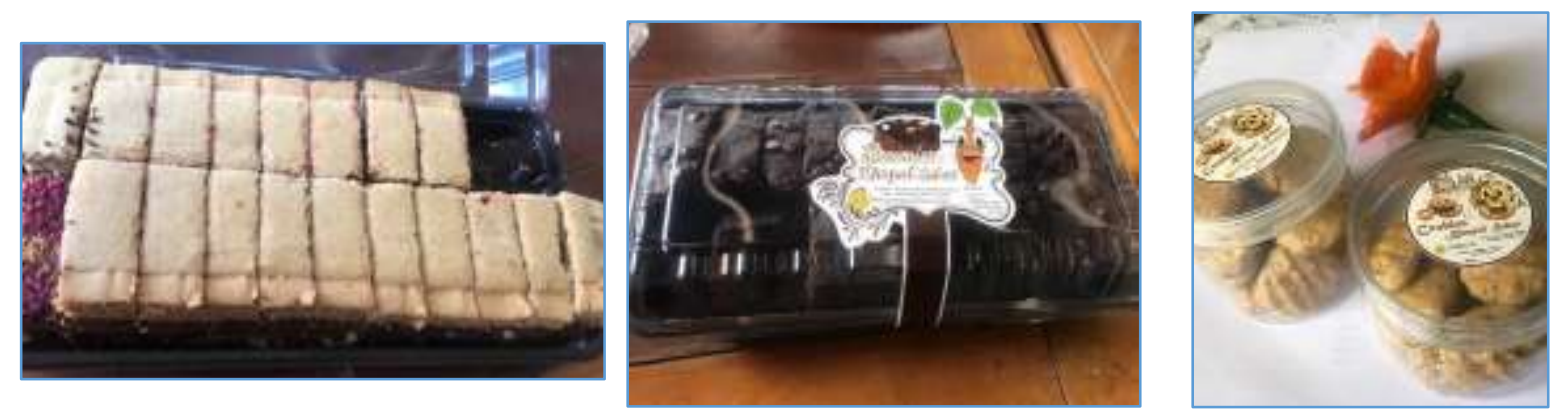

Figure 1. Various snack products based on kimpul with low calories and low sugar 
In this activity, the team has succeeded in encouraging and providing training to UD. Rinjani Cookies in making snacks and cakes for diabetics or those who avoid diabetes. Diversification of cakes is making kimpul cookies, kimpul brownies, kimpul banana cakes, and kimpul layers cake. All made from kimpul flour, non-wheat / gluten-free, low in calories, low in sucrose, and non-trans fat.

The results of testing the amount of nutrition for kimpul cookies are as follows:

Table 1. Nutritional Composition of Kimpul Cookies

\begin{tabular}{ll}
\hline Component & Amount \\
\hline Moisture (\%) & 5.70 \\
Ash content (\%) & 3.08 \\
Fat level (\%) & 18.68 \\
Protein Content (\%) & 9.41 \\
Carbohydrate Content (\%) & 63.13 \\
\hline
\end{tabular}

Based on the table above, the two snacks for diabetics have low sugar and carbohydrate levels. So, the number of Kimpul Cookies Calories is 458.28 calories / 100 gr; 1 cookie weighs an average of 9 grams $=41.24$ calories.

\section{Calorie requirements}

Consumption of healthy snacks must also be accompanied by the pattern and number of calories consumed. The number of calories consumed should not be excessive. The following calculations are used to measure the number of snacks consumed.

Table 2. Calories needed every day based on BMI (Body Mass Index) and type of activity

\begin{tabular}{lllll}
\hline Weight & $\begin{array}{l}\text { BMI (Body Mass } \\
\text { Index) }\end{array}$ & $\begin{array}{l}\text { Light Physical } \\
\text { Activity }\end{array}$ & $\begin{array}{l}\text { Moderate Physi- } \\
\text { cal Activity }\end{array}$ & $\begin{array}{l}\text { Strenuous Physi- } \\
\text { cal Activity }\end{array}$ \\
\hline Less & $<18.5$ & $35 \mathrm{cal} / \mathrm{kg}$ & $40 \mathrm{cal} / \mathrm{kg}$ & $40-45 \mathrm{cal} / \mathrm{kg}$ \\
Normal & $18.5-22.9$ & $30 \mathrm{cal} / \mathrm{kg}$ & $35 \mathrm{cal} / \mathrm{kg}$ & $40 \mathrm{cal} / \mathrm{kg}$ \\
More & $>=23$ & $20 \mathrm{cal} / \mathrm{kg}$ & $30 \mathrm{cal} / \mathrm{kg}$ & $35 \mathrm{cal} / \mathrm{kg}$ \\
\hline
\end{tabular}

Example:

Keke has a weight of $58 \mathrm{~kg}$ and a TB of $1.6 \mathrm{~m}$, then his BMI = 58: $(1.6) 2=22.6$

Because BMI of 22.6 is normal body weight, in general, the total calories needs for each day are:

$58 \times 30 \mathrm{cal}=1740 \mathrm{cal}$ (light physical activity)

$58 \times 35 \mathrm{cal}=2030 \mathrm{cal}$ (moderate physical activity)

$58 \times 40 \mathrm{cal}=2320 \mathrm{cal}$ (strenuous physical activity)

So, to consume kimpul cookies, for someone with light activity with a BMI of 22.6, they can consume 300 grams (about 40 pieces) with 1374.84 calories. If in a day you consume a lot of things other than cookies, then the other foods must be calculated first. The portion of snacks (cakes) for diabetes is recommended for high-calorie cookies, just 2-3 pieces. As for kimpul cookies, because they are low in calories, they can consume up to 6 cookies.

\section{Conclusion}

This service community activity had succeeded in encouraging the Rinjani Cookies Home Industry to produce a variety of cookies and cakes. These two snacks had criteria as cakes that are 
low in calories, low in sugar, and low in animal fat. This snack is suitable for diabetics and consumers who avoid diabetes. Kimpul cookies had as many calories: 458.28 calories /100 gr in one piece contains 41.24 calories so that this kimpul cookies can be recommended as a snack for people with type 2 diabetes which is expected to help control blood glucose without causing a high increase in blood glucose.

\section{Acknowledgment}

We would like to thank Universitas Pembangunan Nasional "Veteran" Jawa Timur through LPPM who has provided funding for the Community Innovation Service Program (BIMA) with training and mentoring at UD. Rinjani Cookies in making various snacks for diabetics.

\section{References}

Istiqomah, A., \& Ristanti, N. (2015). Indeks glikemik, bebab glikemik, kadar protein, serat, dan tingkat kesukaan kue kering tepung garut dengan substitusi tepung kacang merah. Journal of Nutrition College, 4(2), 620- 627

Krisnatuti \& Yehrina. (2008). Diet sehat untuk penderita Diabetes mellitus. Jakarta: Penebar Swadaya.

Mayawati, H., \& Farida, N, I. (2017). Hubungan asupan makanan indeks glikemik tinggi dan aktivitas fisik dengan kadar glukosa darah pada pasien diabetes mellitus tipe ii rawat jalan di RSUD Karanganyar. Jurnal Kesehatan, 10(1), 75-83

Suiraoka. (2012). Penyakit degeneratif. Yogyakarta: Nuhamedika.

Tandra. (2009). Segala sesuatu yang harus anda ketahui tentang diabetes. Jakarta: Kompas Gramedia. 